\title{
Tahap Preliminary Research Pengembangan LKPD Matematika Berbasis Konstruktivisme Materi Program Linier
}

\author{
Rahma Oktaviani ${ }^{1}$, Zulfah ${ }^{2}$ \\ ${ }^{1,2}$ Pendidikan Matematika, Universitas Pahlawan Tuanku Tambusai Bangkinang, Riau \\ *rahmaoktaviani14@gmail.com
}

\begin{abstract}
Abstrak
Tujuan penelitian ini adalah melakukan analisis tahap awal dalam mengembangkan Lembar Kerja Peserta Didik berbasis Konstruktivisme untuk memfasilitasi kemampuan pemahaman konsep matematis peserta didik secara optimal. Penelitian ini menggunakan model Borg and Gall yang terdiri dari sepuluh tahap, namun pada penelitian ini hanya dilakukan tahap pertama yaitu tahap preliminary reseacrh. Untuk tahap pertama yaitu tahap awal penelitian dilakukan analisis kebutuhan, analisis peserta didik, analisis kurikulum, analisis konsep, serta analisis bahan ajar yang ada. Berdasarkan hasil analisis pendahuluan, maka dapat diperoleh kesimpulan bahwa untuk dapat mengasah kemampuan pemahaman konsep matematis peserta didik guru membutuhkan perangkat pembelajaranyang dapat membantu memfasilitasi peserta didik untuk menumbuh dan mengembangkan kemampuan pemahaman konsep matematisnyapadamateri program linier. Melalui LKPD yang didasarkan pada salah satu strategi atau pendekatan yang telah terbukti untuk meningkatkan kemampuan pemahaman konsep yaitu Konstruktivisme, maka akan mendapatkan hasil yang dapat membantu peserta didik mengembangkan kemampuan pemahaman konsepnya.
\end{abstract}

Kata kunci : Konstruktivisme; LKPD; Program Linier.

\begin{abstract}
This research intends to lead an initial analysis in developing students' worksheets (LKPD) based on constructivism to facilitate the students' ability in understanding the mathematical concepts optimally. This research used the Borg and Gall Model which consists of ten stages, but in this study conducted the first stages, preliminary research stage. The first step is the initial stage of the research; it needed analysis, students' analysis, curriculum analysis, construct analysis, and analysis of existing teaching materials. Based on the results of the preliminary analysis, it can be concluded that to be able to fortify students' ability in understanding the mathematical concepts, the teachers need learning tools that will help students learn and expand their skills in understanding mathematical concepts in the linear program material. The students' worksheet, which is based on one of the methods that have been shown to enhance the ability to understand concepts, namely Constructivism, should provide information that will help students improve the ability to understand their concepts.
\end{abstract}

Keywords: Constructivism; Students' Worksheet; Linear Program

\section{PENDAHULUAN}

Pendidikan mempunyai peranan yang sangat penting dalam usaha meningkatkan sumber daya manusia. Hal ini karena dengan pendidikan manusia belajar untuk menghadapi masalah-masalah yang ada dalam kehidupan sehari-hari. Permasalahan dalam kehidupan sehari-hari banyak yang berkaitan dengan masalah matematis. Sebagai contoh perhitungan 
untung dan rugi dalam perdagangan, perhitungan pajak, perhitungan luas bangunan, dan masih banyak lagi masalah-masalah matematis yang lainnya. Hal ini berarti matematika perlu dipelajari untuk memecahkan masalah dalam kehidupan sehari-hari.

Matematika merupakan ilmu yang universal. Matematika juga merupakan suatu mata pelajaran yang abstrak. Istilah abstrak sering dipakai sebagai kata sifat yang mengandung arti sebuah ide yang masih sulit untuk dipahami. Keabstrakan dari pelajaran matematika dapat kita lihat pada materi yang berupa lambang bilangan, simbol, garis, dan istilah lain yang digunakannya.

Sejauh ini, pelajaran matematika masih dianggap sebagai mata pelajaran yang sukar dipahami oleh siswa. Salah satu alasannya karena matematika mempunyai objek yang bersifat abstrak yang tidak dapat dilihat bentuk nyatanya dan sulit dibayangankan oleh siswa secara langsung dan membutuhkan pemahaman konsep yang baik dalam memahami materi (Nurzazili, Irma, \& Rahmi, 2018)

Menurut Depdiknas (2007), salah satu tujuan pembelajaran matematika adalah agar peserta didik memiliki kemampuan memahami konsep matematika, menjelaskan keterkaitan antar konsep, dan mengaplikasikan konsep atau logaritma secara akurat, efisien, dan tepat dalam mengkomunikasikan gagasan dengan simbol, tabel, diagram, atau media lain untuk memperjelas masalah. Pemahaman konsep merupakan hal yang mendasar untuk melangkah pada tahap-tahap berpikir selanjutnya. Untuk itu, pemahaman terhadap konsep-konsep perlu diperdalam lagi. Menurut (Ansari, 2003) dalam Istilah pemahaman berbeda menurut siapa yang memahami sesuatu, apa yang dipahami dan cara atau bagaimana ia memahami hal tersebut. Menurut Rusman (Putri \& Prihatnani, 2020) menyatakan bahwa pemahaman adalah suatu proses individu dalam menerima dan juga memahami informasi yang ia peroleh dari pembelajaran yang ia dapat. Menurut Qohar (Gardenia, 2016) Hal ini serupa dengan pandangan Huggins bahwa untuk meningkatkan pemahaman konseptual matematis, peserta didik melakukannya dengan mengemukakan ide-ide matematisnya.

Berdasarkan hal tersebut,tujuan pembelajaran matematika di sekolah bukan hanya untuk mengenal ilmu berhitung saja, akan tetapi lebih jauh lagi yaitu diharapkan dapat membentuk pola pikir secara logis, sistematis dan kritis. Tercapainya tujuan pembelajaran matematika memerlukan usaha yang dilakukan oleh guru. Salah satu usaha yang dilakukan yaitu dengan menggunakan pendekatan, strategi dan metode yang khusus agar peserta didik merasa senang dan tertarik untuk mempelajari matematika. Menurut Chiang "Saat merancang kegiatan mengajar, seorang guru harus menggunakan indikator kompetensi sebagai tolak ukur dan integrasinya dengan bahan ajar untuk mengubahnya menjadi konten pelajaran, sehingga 
nantinya ini dapat membantu siswa memahami kekuatan dan kelemahan mereka dalam pembelajaran dan dapat membimbing siswa dalam merefleksi diri dan memperbaiki pembelajaran mereka" (Aditya \& Indra, 2017)

Namun, faktanya pendekatan, strategi pembelajaran, metode atau evaluasi dari guru tidak sesuai dengan topik pokok bahasan yang diajarkan. Berdasarkan hasil wawancara dengan salah satu guru kelas XI SMA diketahui bahwa masih banyak peserta didik yang belum memenuhi nilai rata- rata kemampuan pemahaman konsep. Hal ini terlihat dari soalsoal kemampuan pemahaman konsep yang diberikan.

Hal ini disebabkan oleh beberapa faktor diantaranya : 1) Proses pembelajaran matematika dilakukan dengan ceramah, tanya jawab, dan pemberian tugas-tugas secara klasikal, sehingga hanya beberapa peserta didik yang mendengarkan penjelasan guru, sementara beberapa peserta didik yang lain membicarakan mata pelajaran yang lain, menggambar, bahkan ada yang tertidur, 2) Peserta didik merasa takut salah untuk menyelesaikan masalah yang ada, 3) Selain itu, ketika peserta didik diminta untuk mengerjakan soal atau menyelesaikan masalah yang ada, mereka hanya memindahkan jawaban peserta didik yang sudah selesai mengerjakan.

Rendahnya prestasi belajar matematika siswa dipengaruhi oleh beberapa faktor. Salah satu faktornya adalah proses belajar mengajar. Pembelajaran matematika yang selama ini dilaksanakan oleh guru masih menganut pada teori tabula rasa John Locke. Teori tersebut menyatakan bahwa pikiran seorang anak adalah seperti kertas kosong yang putih bersih dan siap menunggu coretan-coretan gurunya. Dengan kata lain, otak seorang anak adalah ibarat botol kosong yang siap diisi dengan segala ilmu pengetahuan dan kebijaksanaan guru. (Apriani, 2017).

Berikut contoh pengerjaan peserta didik pada materi program linier

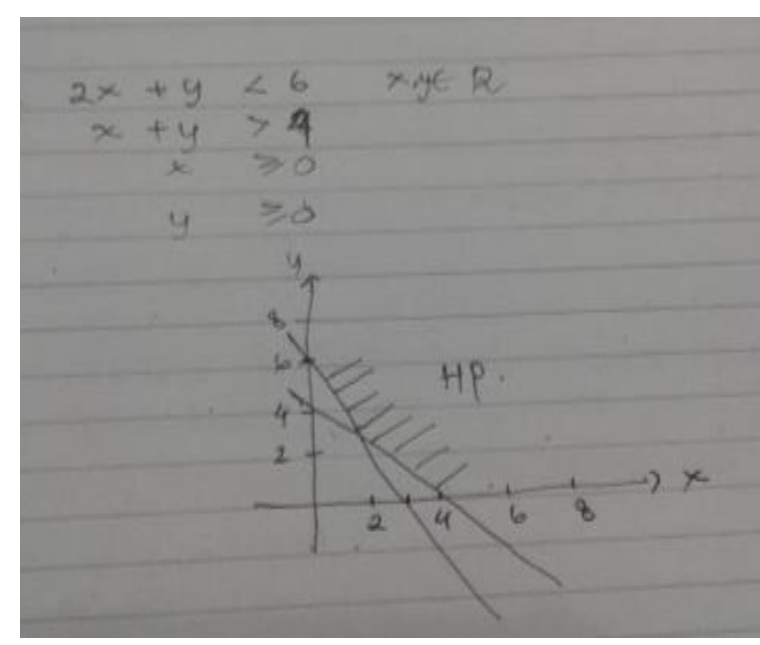

Gambar 1. Lembar Pengerjaan Soal 
Berdasarkan Gambar 1 tersebut terlihat bahwa peserta didik tidak dapat menyelesaikan soal yang diberikan, mereka mengalami kesulitan dalam menyelesaikan soal yang diberikan. Peserta didik tidak mengetahui langkah awal dalam penyelesaian soal. Hal ini disebabkan karena peserta didik menghapal konsep dan rumus-rumus. Hal ini berarti pemahaman konsep yang dimiliki masih perlu ditingkatkan. Hal ini sejalan dengan pendapat Trianto (Agustina, 2016) yang menyatakan bahwa kenyataan dilapangan siswa hanya menghafal konsep dan kurang mampu menggunakan konsep tersebut jika menemui masalah dalam kehidupan nyata yang berhubungan dengan konsep yang dimiliki.

Menurut Turmudi (Riyanto \& Siroj, 2011) bahwa strategi pembelajaran yang bersifat menekankan kepada hafalan (drill) atau rote learning serta mengutamakan kepada routine computation atau algebraic procedural hendaknya sudah harus dikurangi dan diganti dengan cara menekankan kepada pemahaman.

Pendekatan belajar matematika dengan menghapal rumus-rumus yang tidak dikaitkan dengan masalah-masalah dalam kehidupan sehari-hari, sebagai persoalan matematis, tidak melatih peserta didik berpikir kritis dan kreatif. Dengan demikian guru dalam pengajarannya masih dianggap kurang memperhatikan pemahaman konsep peserta didik. Padahal pemahaman konsep merupakan hal mendasar yang harus dimiliki peserta didik yang harus dimiliki untuk melangkah pada tingkat berpikir selanjutnya.

Berdasarkan pemikiran di atas, dipandang perlu adanya pembaharuan proses pembelajaran matematika pada situasi dan kondisi peserta didik saat ini, guna meningkatkan pemahaman konsep peserta didik. Salah satu pembaharuan proses pembelajaran tersebut dengan mengembangkan media untuk membantu peserta didik mengungkapkan apa yang dipikirkan, mengembangkannya dan menghasilkan suatu pengetahuan yang dapat diingat dalam jangka waktu yang lebih lama. Lembar Kerja Peserta didik (LKPD) merupakan panduan bagi peserta didik dalam memahami keterampilan proses dan konsep-konsep materi yang sedang dan akan dipelajari (Astuti \& Setiawan, 2013)

Menurut Permendikbud No. 81 Tahun 2013 kegiatan pembelajaran pada kurikulum 2013 diarahkan untuk memberikan pengalaman belajar kepada peserta didik untuk mengkonstruksi pengetahuan melalui pengalaman-pengalamannya. pendekatan konstruktivisme efektif untuk meningkatkan hasil belajar matematis siswa (Mulyati, 2012). Pendekatan konstruktivisme dapat menjadikan peserta didik lebih mudah memahami konsep, peserta didik akan memahami konsep secara utuh dari pengetahuan riil menuju pengetahuan secara abstrak. 
Hal ini juga didasari oleh penelitian sebelumnya dari Kirana (2017) bahwa melalui pendekatan konstruktif berbantu dengan LKS dapat meningkatkan pemahaman konsep matematis. Selain itu, didukung oleh penelitian Muchlis \& Maizora (2018) bahwa dengan pembelajaran konstruktif berbantuan media dapat membantu peserta didik memahami suatu materi. Dan penelitian yang dilakukan oleh Rahayu (2018) yang menghasilkan LKPD matematika berbasis berbasis pemecahan masalah yang bisa memfasilitasi kemampuan pemahaman konsep peserta didik.

Struktur pengetahuan dapat dikembangkan dengan pengetahuan konsep untuk pengembangan keterampilan pengetahuan (kognitif), misalnya model pembelajaran pembentukan konsep (concept formation), penerimaan konsep (concept reception) dan pencapaian konsep (concept attaiment) serta dapat pemecahan masalah (problem solving). Pada akhirnya perlu dikembangkan bahan ajar matematika dalam bentuk lembar kegiatan peserta didik berbasis pendekatan yang tepat pada setiap pokok bahasan yang dapat meningkatkan kemampuan pemahaman konsep matematis peserta didik. Pengembangan yang dipilih dalam hal ini adalah pengembangan LKPD berbasis pendekatan konstruktif. LKPD adalah panduan bagi peserta didik untuk melakukan kegiatan penyelidikan atau pemecahan masalah (Zulfah, 2017) Menurut Baharuddin (Meini, Hasanuddin, \& Djufri, 2017) LKPD konstruktivistik dirancang untukmemberi kesempatan kepada siswa untuk mengungkapkangagasan yang mereka miliki sehinggamendorong siswa untuk memperluas pengetahuannya berkaitan dengan masalah yang diberikan.

Pembelajaran dengan pendekatan konstruktif akan memfasilitasi peserta didik untuk mengkonstruksi pengetahuan-pengetahuan dan konsep-konsep. Sehingga peserta didik tidak hanya menerima materi dari guru tetapi juga berusaha mengkonstruksi pengetahuan dengan pengalaman-pengalaman yang peserta didik miliki.

\section{METODE}

Penelitian ini merupakan jenis Research and Development (R \& D) atau penelitian dan pengembangan. Research and Development adalah metode penelitian yang digunakan untuk menghasilkan produk tertentu, dan menguji keefektifan produk tersebut (Sugiyono, 2013). Pada penelitian ini hanya dilakukan tahap pertama yaitu tahap Reseacrh and information Colleting. Produk yang dihasilkan dari penelitian ini berupa LKPD pembelajaran khusus kelas XI SMA materi Program Linier berbasis pendekatan konstruktif untuk mengembangkan pemahaman konsep peserta didik. 
Penelitian pengembangan ini dilakukan dengan mengacu pada prosedur R\&D dari Borg and Gall (1989) ada 10 langkah pelaksanaan strategi penelitian dan pengembangan Borg dan Gall yaitu:

Tabel 1. Langkah-langkah penelitian yang dikemukakan Bord dan Gall

\begin{tabular}{lll}
\hline No & Langkah utama Borg dan Gall & 10 langkah Bord dan Gall \\
\hline 1 & $\begin{array}{l}\text { Penelitian dan pengumpulan inforasi } \\
\text { (Research dan information Collecting) }\end{array}$ & $\begin{array}{l}\text { 1. Penelitian dan pengumpulan } \\
\text { informasi }\end{array}$ \\
\hline 2 & Perencanaan (Planning) & 2. Perencanaan \\
\hline 3 & Pengembangan bentuk awal produk & 3. Pengembangan bentuk awal \\
& (Develop Preliminary from of product) & produk \\
\hline 4 & Uji lapangan dan revisi produk & 4. Uji coba lapangan awal \\
& (FieldTesting and Product Revision) & 5. Revisi produk \\
& & 6. Uji lapangan utama \\
& & 7. Revisi produk operasional \\
& 8. Uji lapangan opersional \\
\hline 5 & Revisi produk akhir (Final & 9. Revisi produk akhir \\
& ProductRevision) & \\
\hline 6 & Diseminasi dan implementasi & 10. Diseminasi dan Implementasi \\
& (Dissemination and Implementation) & \\
\hline
\end{tabular}

\section{HASIL PENELITIAN}

Analisis pendahuluan dilakukan peneliti pada peserta didik kelas XI SMA. Hasil dari tahapan alisis terbagi menjadi hasil analisis kebutuhan, hasil analisis peserta didik, hasil analisis kurikulum, serta hasil analisis konsep.

\section{Self Evaluation Analysis}

Tahap analisis dilakukan dengan tujuan untuk memperoleh informasi mengenai permasalahan yang terdapat pada dunia pendidikan. Selain itu melalui tahap analisis, peneliti memperoleh gambaran sementara dari produk yang dikembangkan. Pada tahap analisis dilakukan analisis kebutuhan, analisis kurikulum, analisis peserta didik, dan analisis konsep. Pada tahap analisis kebutuhan, peneliti mengumpulkan informasi mengenai permasalahan yang terdapat dalam pembelajaran matematika dengan mengobservasi pelaksanaan kegiatan pembelajaran, mewawancarai guru matematika dan peserta didik. Hal ini bertujuan untuk mengetahui gambaran permasalahan yang terdapat dalam pembelajaran matematika dan penyebabnya, pelaksanaan pembelajaran serta penggunaan perangkat pembelajaran. 
Pada tahap analisis kurikulum dilakukan telaah terhadap kurikulum yang digunakan yaitu kurikulum 2013. Analisis tersebut bertujuan untuk mengetahui tujuan, isi materi kelas XI SMA yang akan dikembangkan serta untuk mengetahui kemampuan yang harus dimiliki peserta didik setelah mempelajari materi tersebut.

\section{PEMBAHASAN}

Analisis peserta didik dilakukan untuk mengetahui kualitas individual peserta didik yang merupakan telaah dari kebutuhan peserta didik dan dapat dijadikan petunjuk dalam perancangan perangkat pembelajaran yang akan dibuat. Hal yang dilakukan adalah melihat kecenderungan belajar, karakteristik peserta didik dalam berfikir, dan keterampilan peserta didik dalam belajar serta ketertarikan peserta didik dalam menggunakan LKPD. Kegiatan yang dilakukan pada tahap ini adalah memberikan angket kepada peserta didik yang memuat pernyataan-pernyataan tentang spesifikasi LKPD yang diharapkan. Analis ini dijadikan pertimbangan dalam merancang LKPD berbasis Konstruktivisme. Sedangkan analisis konsep bertujuan untuk mengidentifikasi konsep-konsep utama yang diajarkan, merinci, dan menyusunnya secara sistematis untuk mencapai indikator-indikator pencapaian kompetensi.

\section{Analisis Kebutuhan}

Peneliti melakukan analisis kebutuhan dengan wawancara. Wawancara dilakukan dengan guru kelas XI Sekolah Mengengah Atas (SMA/MA/MAK). Wawancara tersebut bertujuan untuk mengetahui permasalahan yang dihadapi di lapangan sesuai dengan fakta yang terjadi. Secara umum permasalahan yang terjadi adalah berkaitan dengan implementasi mengenai kurikulum 2013 pada proses pembelajaran dan ketersediaannya perangkat pembelajaran untuk mencapai proses pembelajaran.

Wawancara yang dilakukan berpedoman pada 7 butir pertanyaan untuk melakukan analis kebutuhan perangkat pembelajaran yang sesuai dengan kurikulum 2013. Berikut adalah data hasil wawancara yang akan dijelaskan pada setiap butirnya. Butir pertama, yaitu mengenai proses pembelajaran yang berlangsung selama ini, Guru memberikan jawaban proses pembelajaran yang berlangsung sudah sesuia dengan kurikulum yang dipakai yaitu kurikulum 2013. Butir kedua, yaitu terkait penggunaan LKPD pada proses pembelajaran. Guru menjawab tidak ada menggunakan LKPD tetapi sebelumnya ada. Butir ketiga, yaitu mengenai LKPD seperti apa yang digunakan. Guru menjawab LKPD biasa yang hanya berisi soal-soal.

Butir keempat, yaitu mengenai respon peserta didik terhadap LKPD tersebut, Guru menjawab peserta didik merasa bosan karena selalu diberikan tugas mengerjakan soal-soal. 
Butir kelima, yaitu apakah LKPD tersebut dapat menuntun peserta didik dalam memahami materi. Guru menjawab tidak karena pada LKPD hanya berisi soal-soal dan tidak ada materi didalamnya. Butir keenam, yaitu mengenai ketertarikan peserta didik dengan pembelajaran menggunakan LKPD, guru menjawab tergantung LKPD yang digunakan apakah menarik atau tidak. Butir ketujuh, yaitu mengenai LKPD seperti apa yang disukai peserta didik, guru menjawab yang menarik dan bisa memotivasi siswa dalam memahami materi pembelajaran.

\section{Analisis Kurikulum}

Pada tahap ini dilakukan telaah kurikulum 2013 untuk mata pelajaran matematika kelas XI SMA. Analisis ini menjadi pedoman dalam melakukan pengembangan perangkat pembelajaran berbasis Konstruktivisme. Analisis untuk kompetensi dasar materi ini adalah dikembangkannya indicator dengan menggunakan pembelajaran Konstruktivisme untuk mengorganisasikan materi dan menentukan tujuan pembelajaran yang ingin dicapai. Semua indikator yang dirancang telah disesuaikan dengan $\mathrm{KD}$ dan indikator pemahanam konsep namun tidak lepas dari kehidupan nyata.

Hasil penjabaran indikator pembelajaran untuk kompetensi inti pengetahuan pada materi program linier yang diujicobakan dapat dilihat pada tabel 2 berikut ini :

Tabel 2. Kompetensi Dasar dan Indikator

\begin{tabular}{|c|c|}
\hline Kompetensi Dasar & Indikator \\
\hline 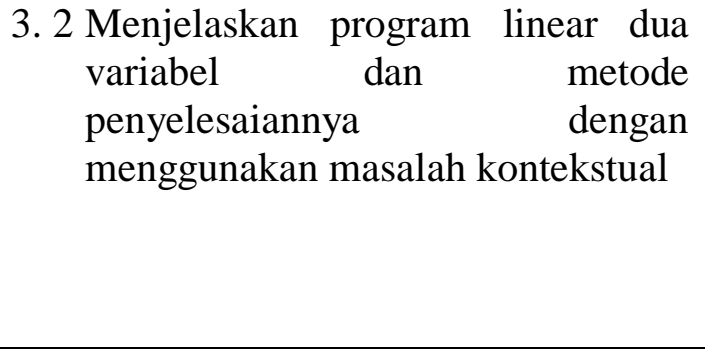 & $\begin{array}{l}\text { - Menjelaskan pengertian program linear dua } \\
\text { variabel } \\
\text { - Menjelaskan sistem pertidaksamaan linier dua } \\
\text { variabel } \\
\text { - Menjelaskan nilai optimum fungsi objektif } \\
\text { - Menjelaskan penerapan program liniear dua } \\
\text { variabel dalam menyelesaikan masalah }\end{array}$ \\
\hline $\begin{array}{l}\text { 4.2 Menyelesaikan masalah kontekstual } \\
\text { yang berkaitan dengan program } \\
\text { linear dua variable }\end{array}$ & $\begin{array}{l}\text { - Memecahkanmasalah yang berkaitandengan } \\
\text { program linear duavariabel } \\
\text { - Menyajikanpenyelesaianmasalah yang } \\
\text { berkaitandengan program linear duavariable }\end{array}$ \\
\hline
\end{tabular}

Berdasarkan analisis isi kurikulum pada tabel 2. Susunan KD dengan indikator sudah sesuai. Karena sebelum melakukan penyelesaian terhadap suatu permaslahan, terlebih dahulu peserta didik diharapkan mampu memahami konsep terkait permasalahan yang diberikan.

\section{Analisis Peserta Didik}

Analisis Peserta didik dilakukan peneliti dengan memberikan sebuah angket yang berisi pernyataan-pernyataan mengenai proses pembelajan yang akan ditanggapi oleh peserta 
didik.Analisis dilakukan untuk mengetahui kajian tentang karakteristik peserta didik yang sesuai dengan perancangan LKPD. Karakteristik peserta didik yang dimaksud adalah aktivitas belajar matematika. Dari hasil observasi dapat disimpulkan bahwa peserta didik membutuhkan sebuah LKPDberbasisKonstruktivisme yang bisa membantunya dalam memahami materi pelajaran.

Dalam pembelajaran matematika dengan pendekatan konstruktivisme, siswa mengkonstruk sendiri pengetahuannya di dalam benaknya baik secara individu maupun bersama teman (diskusi), dalam usaha mengembangkan kemampuan penalarannya, seperti yang dikemukakan oleh Wallace, Engel dan Mooney (dalam Asra, 2007) bahwa teori belajar kognitif memiliki postulat "untuk pengembangan penalaran pembelajaran harus dalam bentuk diskusi kelompok".

\section{Analisis Konsep}

Analisis konsep bertujuan untuk menentukan isi dan materi pelajaran yang dibutuhkan dalam pengembangan LKPD yang akan dihasilkan, dengan cara mengidentifikasi konsepkonsep utama yang diajarkan, merinci dan menyusun nya secara sistematis sesuai dengan urutan penyajiannya. Pemilihan materi ajar dilakukan dengan mempertimbangkan kesesuaian konsep dan isi materi. Setelah itu, materi dirinci dan disusun secara sistematis ke dalam LKPD yang dikembangkan agar saling berkesinambungan untuk mendukung terlaksananya pembelajaran. Materi yang terpilih dalam penelitian ini adalah Program Linier kelas XI.

\section{SIMPULAN}

Berdasarkan uraian hasil dan pembahasan diatas menunjukkan bahwa guru disekolah membutuhkan bahan ajar yang dapat memfasilitasi kemampuan pemahaman konsep peserta didik. Lembar Kerja Peserta Didik (LKPD) berbasis kontruktivisme sangat dibutuhkan untuk membantu peserta didik dalam mengembangkan kemampuan pemahaman konsepnya. Selain itu, pembelajaran dengan menggunakan LKPD berbasis Konstruktivisme mengajak peserta didik aktif mulai dari awal proses pembelajaran. Peserta didik juga diajarkan bagaimana cara menentukan suatu makna atau konsep dari suatu materi pelajaran.

\section{REFERENSI}

Aditya, H. \& Indra, I. (2017). Pengembangan LKS Berbasis RME dengan Pendekatan Problem Solving untuk Memfasilitasi Kemampuan Pemecahan Masalah Matematis Siswa. Jurnal Cendikia, 1(2), 51-63. https://doi.org/10.31004/cendekia.v1i2.20 
Agustina, L. (2016). Upaya Meningkatkan Kemampuan Pemahaman Konsep dan Pemecahan Masalah Matematika Siswa SMP Negeri 4 Sipirok kelas VII melalui Pendekatan Matematika Realistik (PMR). EKSAKTA: Jurnal Penelitian Dan Pembelajaran MIPA, 1(1), 1-7. http://dx.doi.org/10.31604/eksakta.v1i1.\%25p.

Ansari, B. (2003). Menumbuh kembangkan Kemampuan Pemahaman dan Komunikasi Matematik melalui Strategi Think-Talk-Write (Eksperimen di SMUN kelas I Bandung). Universitas Pendidikan Indonesia.

Apriani, D. (2017). Pengembangan Lembar Kerja Siswa (LKS) Berbasis Konstruktivis Pada Materi Ruang Dimensi Tiga Di SMA. Jurnal Penelitian Pendidikan Matematika, 1(1), 29-38. https://doi.org/10.32502/jp2m.v1i1.682

Asra, S. (2007). Metode Pembelajaran. Bandung: CV Wacana Prima

Astuti, Y., \& Setiawan, B. (2013). Pengembangan lembar kerja siswa (LKS) berbasis pendekatan inkuiri terbimbing dalam pembelajaran kooperatif pada materi kalor. Jurnal Pendidikan IPA Indonesia, 2(1), 88-92. https://doi.org/10.15294/jpii.v2i1.2515

Depdiknas. (2007). Standar Isi Untuk Satuan Pendidikan Dasar dan Menengah. Jakarta: Dirjen Dikti Depdiknas

Gardenia, N. (2016). Peningkatan Kemampuan Pemahaman dan Komunikasi Matematis Siswa SMK Melalui Pembelajaran Konstruktivisme Model Needha. Formatif: Jurnal Ilmiah Pendidikan MIPA, 6(2), 110-118. http://dx.doi.org/10.30998/formatif.v6i2.944

Kirana, J. C. (2017). Pengembangan Lembar Kerja Siswa Berbasis Konstruktivisme Pada Materi Barisan dan Deret Kelas X Akuntansi SMKN 1 Kota Solok. THEOREMS (THE jOuRnal of mathEMatics), 2(1), 51-57.

Meini, M., Hasanuddin, H., \& Djufri, D. (2017). Pengaruh Pembelajaran Berbasis LKPD Konstruktivistik terhadap Hasil Belajar Kognitif Siswa pada Konsep Makanan dan Sistem Pencernaan Di SMA Negeri 12 Banda Aceh. Jurnal Edubio Tropika, 5(1), 33 37.

Muchlis, E. E., \& Maizora, S. (2018). Upaya Meningkatkan Kemampuan Pemahaman Konsep Trigonometri Melalui Pendekatan Konstruktivisme dengan Berbantukan Macromedia Flash 8 Pada Mahasiswa Program Studi Pendidikan Matematika FKIP Universitas Bengkulu. Jurnal Riset Pendidikan Matematika Jakarta, 1(1), 39-44.

Mulyati, T. (2012). Pendekatan Konstruktivisme dan Dampaknya Bagi Peningkatan Hasil Belajar Matematika Siswa SD. EduHumaniora, 1(2)., 1-8. 
Nurzazili., Irma, A., Rahmi, P. (2018). Pengembangan Lembar Kegiatan Siswa (LKS) Berbasis Problem Based Learning (PBL) untuk Memfasilitasi Kemampuan Pemecahan Masalah Matematis Siswa Di SMA Negeri 10 Pekanbaru. Jurnal Cendekia: Jurnal Pendidikan Matematika, 2(1), 172-179. https://doi.org/10.31004/cendekia.v2i1.43

Putri, Y. E., \& Prihatnani, E. (2020). Perbandingan PBL Dan DL Terhadap Pemahaman Konseptual Siswa Kelas XI Ditinjau Dari Motivasi Belajar. Jurnal Cendekia: Jurnal Pendidikan Matematika, 4(1), 40-52. https://doi.org/10.31004/cendekia.v4i1.154

Rahayu, D. (2018). Pengembangan Lembar Kerja Peserta Didik (Lkpd) Berbasis Pemecahan Masalah Materi Bangun Datar. Jurnal Penelitian Pendidikan Guru Sekolah Dasar, 6(3), 249-259.

Riyanto, B., \& Siroj, R. A. (2011). Meningkatkan kemampuan penalaran dan prestasi matematika dengan pendekatan konstruktivisme pada siswa sekolah menengah atas. Jurnal Pendidikan Matematika, 5(2), 111-128.

Sugiyono. (2013). Metode Penelitian Pendidikan Pendekatan Kuantitatif, Kualitatif, dan $R \& D$. Bandung: Alfabeta.

Zulfah, Z. (2017). Tahap Preliminary Research Pengembangan Lkpd Berbasis PBL untuk Materi Matematika Semester 1 Kelas VIII Smp. Jurnal Cendekia: Jurnal Pendidikan Matematika, 1(2), 1-12. https://doi.org/10.31004/cendekia.v1i2.59 